\title{
Changes in Furan Fatty Acids of Testis Lipids of Chum Salmon Oncorhynchus keta at Spawning Season
}

\author{
Toru Ota* and Toru Takagi*
}

(Received September 14, 1989)

\begin{abstract}
Lipid class and fatty acid compositions of the testis lipids of chum salmon Oncorhynchus keta having different maturities [maturing (A), matured (B) and fully matured (C) stages] were examined with particular reference to furan fatty acids ( $\mathrm{F}$ acids).

There were little changes in the lipid content with about $2 \%$ during maturation. The sterol esters (SE) and triacylglycerols (TG) in the testis lipids decreased. On the contrary, the free sterols (ST) tended to increase during maturation.

$F$ acids were found in the SE, TG and free fatty acids (FFA), but not in the phospholipids.

The TG contained large amounts of $\mathrm{F}$ acids compared with other lipid classes. The $\mathrm{F}$ acids of the TG increased with maturation and reached to $44.8 \%$ of the total fatty acids at the fully matured stage. On the contrary, those of the SE and FFA decreased from 18.5 to $6.5 \%$ and from 9.9 to $4.6 \%$, respectively.

The results in this study suggested that the changes in the $\mathrm{F}$ acids of the lipid classes of chum salmon testes during maturation were due to a decline in the lipid metabolism arising from the physiological fluctuation in chum salmon at late spawning season.
\end{abstract}

It has become apparent that $\mathrm{C}_{18} \mathrm{C}_{24}$ furan fatty acids ( $\mathrm{F}$ acids) ${ }^{\mathrm{i}}$, with methyl or dimethyl substituents on the furan ring are found in the lipids of aquatic organisms. ${ }^{2-\theta)}$

In a previous paper, ${ }^{7)}$ the authors have also reported on the occurrence of $F$ acids, especially, an isomer of $F_{B}$ acid (14, 17-epoxy-15, 16-dimethyleicosa-14, 16-dienoic acid), in the lipids of kokanee Oncorhynchus nerka f. adonis.

The $F$ acids in fish lipids are mainly in the cholesterol esters of liver and blood and in the triacylglycerols of testes, ${ }^{8,8)}$ and show various changes in the amount at spawning season. Glass et $a l^{\left({ }^{3)}\right.}$ described that prior to spawning the $F$ acids in the liver of brook trout moved into the testes via blood. Gunstone et al. ${ }^{4)}$ found that a high content of the $\mathrm{F}$ acids in cod liver was closely related to starvation. Such variations of the $F$ acids in fish tissues suggest a close relationship between $F$ acids and fish physiology.

Many problems of the $F$ acid metabolism in fish tissues and on the biological function to fish during maturation still remain unsolved.

In this paper, the distribution of fatty acids with special reference to $F$ acids in the lipid classes of testis lipids of chum salmon Oncorhynchus keta having different maturity was investigated and the possible metabolism of the $F$ acids at spawning season was discussed.

\section{Materials and Methods}

\section{Materials}

Male chum salmon Oncorhynchus keta having an average body weight of $3.6 \mathrm{~kg}$ were captured in November by a set net in the coast of Samani, Hokkaido. A part of them was immediately transferred into a freshwater pond and reared for two weeks. The chum salmon were divided into three groups; seawater fish (A), freshwater fish without (B) and with (C) showing an effluence of semen after hand-stripping.

\section{Extraction and Fractionation of Lipids}

Total lipids of the testes from each group were extracted with chloroform and methanol by the method of Bligh and Dyer. ${ }^{102}$ The lipids were separated into neutral lipids (NL) and phospholipids (PL) by silicic acid (Silica Gel 60) column chromatography using chloroform and methanol as solvents. The NL was subsequently subjected to column chromatography on silicic acid (Wakogel C-200) using n-hexane, diethyl ether and methanol as solvents. ${ }^{11)}$ The incomplete portions of frac-

* Faculty of Fisheries, Hokkaido University, Hakodate 041, Japan（太田 亨, 高木 徹：北海道大学水産 学部). 
tionation were further separated and purified by preparative thin-layer chromatography (TLC, Silica Gel 60G) using n-hexane/diethyl ether/ acetic acid (70:30:1 by vol.) as a solvent. ${ }^{11}$ )

\section{Preparation of Fatty Acid Methyl Esters}

Preparation of the fatty acid methyl esters (FAME) was carried out by refluxing the lipid classes with $0.5 \mathrm{~N}$ sodium methoxide-MeOH or $7 \% \mathrm{BF}_{3}-\mathrm{MeOH}$. Separation of $\mathrm{F}$ acid fraction from the total FAME was carried out by urea fractionation and argentation-TLC. ${ }^{4}$ The total FAME was warmed with urea $(9$ parts) and methanol (50 parts), and this solution was stored at $-20^{\circ} \mathrm{C}$ for $3 \mathrm{hrs}$ and filtered. The non-urea complexing FAME was further fractionated by argentation-TLC (Silica Gel $60 \mathrm{G}$ plates impregnated with $10 \% \mathrm{AgNO}_{3}$ ) using $\mathrm{n}$-hexane/benzene $(1: 1 \mathrm{v} / \mathrm{v})$ as a development solvent. $\left.{ }^{\mathrm{g}}\right)$

\section{Gas-Liquid Chromatography (GLC)}

Analyses of the FAME were performed on a Yanagimoto G80 gas chromatograph equipped with a flame ionization detector. Two glass columns ( $1.5 \mathrm{~m} \times 3 \mathrm{~mm}$ i.d.) packed with $5 \%$ DEGS on Chromosorb WAW (100-120 mesh) and $15 \%$ BDS on Chromosorb WAW (80-100 mesh) were used. ${ }^{8}$ The columns were held at $190^{\circ} \mathrm{C}$ and $/$ or $210^{\circ} \mathrm{C}$.

Individual FAME were identified by a logarithmic plotting procedure of relative retention times vs. carbon numbers. Especially, identification of $F$ acids was performed by comparison with the equivalent chain length (ECL) values of known standards prepared from kokanee lipids. ${ }^{7)}$ Peak area percentages were obtained with Shimadzu integrator E1A.

\section{Results and Discussion}

\section{Lipid Content and Lipid Class Composition}

The lipid content and lipid class composition of chum salmon testes are shown in Table 1. There were no remarkable differences in the lipid contents among the three groups ranging from 2.0 to $2.6 \%$ on the wet weight. These values were similar to those of walleye pollock testes $(2.5 \%)^{123}$ and maturing rat testes $(2.38-2.64 \%)^{13)}$

The testis lipids were high in PL and low in triacylglycerols (TG). In addition, a relatively high content of free fatty acids (FFA) was observed in the testes $B$ and $C$. These results are similar to the values in the study of chum salmon lipids reported by Takahashi et al. ${ }^{14)}$ The sterol
Table 1. Lipid content and lipid class composition of chum salmon testes

\begin{tabular}{|c|c|c|c|}
\hline \multirow{2}{*}{$\begin{array}{c}\text { Habitat } \\
\text { Number of fish }\end{array}$} & \multirow{2}{*}{$\frac{\begin{array}{c}A^{* 1} \\
\text { Seawater }\end{array}}{2}$} & \multicolumn{2}{|c|}{$\begin{array}{l}\text { B }^{* 1} \quad C^{* 1} \\
\text { Freshwater }\end{array}$} \\
\hline & & 4 & 5 \\
\hline Lipid content $(\%)$ & 2.2 & 2.6 & 2.0 \\
\hline \multicolumn{4}{|l|}{$\begin{array}{l}\text { Lipid class ( } \% \text { of } \\
\text { total lipids) }\end{array}$} \\
\hline Sterol esters*2 & 0.7 & 0.4 & 0.3 \\
\hline Triacylglycerols & 12.8 & 5.2 & 2.1 \\
\hline Free fatty acids & 4.3 & 20.0 & 13.4 \\
\hline Sterols & 17.7 & 21.5 & 23.7 \\
\hline Phospholipids & 64.5 & 52.9 & 60.5 \\
\hline
\end{tabular}

*1 A stands for maturing, $B$ matured, and $C$ fully matured testes, *2 Includes a small amount of hydrocarbons.

esters (SE) and TG decreased from 0.7 to $0.3 \%$ and from 12.8 to $2.1 \%$ with maturation, respectively. Such changes were approximately similar to those of maturing rat testes. ${ }^{13)}$ On the contrary, the free sterols (ST) tended to increase during maturation.

\section{Fatty Acid Composition}

Table 2 shows the fatty acid composition of lipid classes from chum salmon testes. The major fatty acids in each lipid class were $16: 0,16: 1$, $18: 0,18: 1,20: 1,20: 5(n-3)$ and $22: 6(n-3)$ as were those of walleye pollock and cod milts. ${ }^{8,12}$ Comparison of the fatty acid compositions among the lipid classes indicated that the TG were rich in 20:1, 22:1 and isoprenoid fatty acids which were composed mainly of pristanic and phytanic acids, and low in 16:0,18:0,20:4(n-6), 20:5(n-3) and 22:6(n-3) compared to those of other lipid classes. Particularly, the content of isoprenoid fatty acids was significantly high in the testis $T G$ compared to that of the lipids from other fish and marine animals $(0.3-1.6 \%)^{18-18)}$ The isoprenoid fatty acids and $22: 6(n-3)$ decreased during maturation. The isoprenoid fatty acids seem to be concentrated in the chum salmon tissues from dietary lipids rather than by endogenous de novo synthesis, as stated by Ackman and Hooper..1? It is of interest to note the reason of high content of these acids in the matured testis lipids in connection with lipidosis such as Refsum's disease in mammals. ${ }^{18)}$

$F$ acids $\left(F_{1}\right.$ to $\left.F_{8}\right)$ were found in the SE, TG and FFA. Particularly, F acid content in the TG was significantly high compared to other lipid classes as well as the results from freshwater fish testes. Glass et $a l^{97}$ have found the F acids in the PL of 
Table 2. Fatty acid composition of lipid classes of chum salmon testes ( $\%$ of total fatty acids)

\begin{tabular}{|c|c|c|c|c|c|c|c|c|c|c|c|c|}
\hline \multirow{2}{*}{ Fatty acid } & \multicolumn{4}{|c|}{$A^{* 1}$} & \multicolumn{4}{|c|}{$\mathrm{B}^{* 1}$} & \multicolumn{4}{|c|}{$C^{* 1}$} \\
\hline & $\mathrm{SE}^{* 2}$ & $T^{* 2}$ & FFA $^{* 2}$ & PL*2 & SE & TG & FFA & PL & SE & $\mathrm{TG}$ & FFA & PL \\
\hline Iso $14: 0$ & - & $\operatorname{Tr}^{* 3}$ & $\mathrm{Tr}$ & $\mathrm{Tr}$ & 0.1 & $\mathrm{Tr}$ & $\mathrm{Tr}$ & - & 0.7 & 0.1 & 0.1 & - \\
\hline $14: 0^{* 4}$ & 0.7 & 4.4 & 2.4 & 2.9 & 0.6 & 2.5 & 1.8 & 3.4 & 0.5 & 1.5 & 1.1 & 2.1 \\
\hline $15: 0$ & 0.3 & 0.1 & 0.2 & 0.4 & 0.2 & 0.1 & 0.3 & 0.5 & 0.7 & 0.2 & 0.3 & 1.8 \\
\hline Pristanic & 0.2 & 2.0 & 0.1 & $\mathrm{Tr}$ & 0.2 & 1.6 & 0.2 & 0.1 & $\operatorname{Tr}$ & 0.7 & 0.1 & 0.1 \\
\hline $16: 0$ & 27.7 & 4.2 & 15.1 & 22.9 & 17.9 & 3.3 & 15.5 & 26.7 & 15.3 & 3.4 & 18.3 & 29.6 \\
\hline Phytanic & 2.4 & 9.7 & 1.6 & 0.4 & 1.8 & 8.0 & 1. 2 & 0.5 & 1.2 & 2.2 & 1.0 & 1.1 \\
\hline $18: 0$ & 3.0 & 0.4 & 11.2 & 2.9 & 2.2 & 0.7 & 4.3 & 3.0 & 2.5 & 1.1 & 6.2 & 3.1 \\
\hline $14: 1$ & 0.2 & 0.1 & $\operatorname{Tr}$ & $\operatorname{Tr}$ & 0.1 & 0.1 & $\mathrm{Tr}$ & $\mathrm{Tr}$ & - & 0.1 & $\operatorname{Tr}$ & $\operatorname{Tr}$ \\
\hline $16: 1$ & 4.7 & 8.2 & 4.8 & 2.0 & 3.2 & 3.9 & 2.9 & 4.2 & 3.5 & 3.4 & 2.7 & 1.4 \\
\hline $17: 1$ & 0.5 & 0.2 & 0.5 & 0.4 & 0.4 & 0.2 & 0.4 & 0.5 & 0.2 & 0.3 & 0.5 & 1.5 \\
\hline $18: 1$ & 12.6 & 19.3 & 29.6 & 18.7 & 11.6 & 15.4 & 17.6 & 19.7 & 12.2 & 17.8 & 20.7 & 19.5 \\
\hline $20: 1^{* 5}$ & 1.7 & 5.1 & 3.4 & 1.9 & 1.8 & 3.9 & 2.5 & 1.9 & 1.8 & 4.5 & 2.1 & 1.8 \\
\hline $22: 1$ & 0.7 & 1.3 & 0.9 & 0.8 & 1.6 & 2.6 & 1.3 & $\operatorname{Tr}$ & 2.2 & 3.3 & 1.2 & $\operatorname{Tr}$ \\
\hline $24: 1$ & $\mathrm{Tr}$ & 0.1 & - & - & - & - & - & - & - & 0.5 & - & - \\
\hline $18: 2(n-6)$ & 0.6 & 1.9 & 1.7 & 0.6 & 1.0 & 1.5 & 1.5 & 0.4 & 1.1 & 1.1 & 1.4 & 0.3 \\
\hline $18: 3(n-6)$ & 0.2 & $\operatorname{Tr}$ & $\operatorname{Tr}$ & $\operatorname{Tr}$ & 0.2 & 0.1 & 0.1 & 0.2 & 0.1 & 0.1 & 0.1 & 0.6 \\
\hline $18: 3(n-3)$ & 0.6 & 3.7 & 1.0 & 0.5 & 1.3 & 1.8 & 1.1 & 0.2 & 1.4 & 1.0 & 0.7 & 0.1 \\
\hline $20: 2(n-6)$ & 0.2 & 0.5 & 0.3 & 0.2 & 0.2 & 0.8 & 0.4 & 0.1 & 0.8 & 0.7 & 0.3 & 0.5 \\
\hline $20: 3(n-6)$ & 0.1 & 0.1 & 0.1 & 0.1 & 0.2 & 0.5 & 0.2 & 0.1 & - & 0.3 & 0.1 & 0.2 \\
\hline $20: 4(n-6)$ & 0.9 & 0.4 & 2.3 & 2.1 & 1.8 & 0.7 & 2.7 & 2.0 & 3.1 & 0.5 & 3.3 & 3.3 \\
\hline $20: 4(n-3)$ & 0.5 & 1.6 & 1.5 & $\operatorname{Tr}$ & $\operatorname{Tr}$ & $\mathrm{Tr}$ & $\operatorname{Tr}$ & 0.3 & $\operatorname{Tr}$ & $\mathrm{Tr}$ & $\operatorname{Tr}$ & $\operatorname{Tr}$ \\
\hline $20: 5(n-3)$ & 14.6 & 5.4 & 10.5 & 23.7 & 22.2 & 6.8 & 21.6 & 21.1 & 30.8 & 4.6 & 18.7 & 19.2 \\
\hline $22: 5(n-6)$ & 0.2 & 0.4 & $\operatorname{Tr}$ & 0.1 & 0.2 & 0.6 & 0.4 & 0.1 & - & 0.4 & 0.4 & 0.2 \\
\hline $22: 5(n-3)$ & 1.2 & 1.3 & 2.7 & 1.8 & 1.7 & 2.8 & 2.7 & 2.8 & 1.8 & 1.8 & 2.7 & 2.0 \\
\hline $22: 6(n-3)$ & 18.1 & 9.0 & 9.1 & 17.6 & 11.1 & 7.3 & 11.4 & 12.2 & 13.5 & 5.5 & 13.5 & 11.7 \\
\hline $\mathrm{F}_{1}^{* \mathrm{~B}}$ & 0.1 & 0.1 & $\operatorname{Tr}$ & 一 & 0.1 & 0.2 & 0.1 & - & 0.1 & 0.2 & 0.1 & - \\
\hline$F_{2}$ & $\operatorname{Tr}$ & 0.2 & $\operatorname{Tr}$ & - & 0.4 & 0.6 & 0.2 & - & - & 0.5 & - & - \\
\hline$F_{3}$ & $\operatorname{Tr}$ & 0.1 & - & - & 0.1 & 0.3 & 0.3 & - & 0.5 & 0.3 & - & - \\
\hline$F_{4}$ & 1.0 & 4.6 & 0.2 & - & 3.6 & 8.0 & 2.4 & - & 0.8 & 5.1 & 0.4 & 一 \\
\hline $\mathbf{F}_{5}$ & 0.6 & 1.3 & 0.2 & - & 0.5 & 3.0 & 0.6 & - & 0.1 & 2.1 & 0.2 & - \\
\hline$F_{8}$ & 6.1 & 12.7 & 0.5 & - & 13.8 & 20.7 & 4.9 & - & 5.0 & 34.7 & 3.7 & 一 \\
\hline$F_{0}^{\prime}$ & 0.1 & 0.4 & $\operatorname{Tr}$ & - & - & 0.5 & 0.2 & - & - & 0.3 & - & - \\
\hline$F_{7}$ & 0.2 & 0.5 & - & - & - & 0.3 & 0.5 & - & - & 0.5 & 0.2 & - \\
\hline $\mathrm{F}_{8}$ & - & 0.7 & - & - & 一 & 1.2 & 0.7 & - & - & 1.1 & - & - \\
\hline Sat. acids & 34.3 & 20.8 & 30.6 & 29.5 & 23.0 & 16.2 & 23.3 & 34.2 & 20.9 & 9.2 & 27.1 & 37.8 \\
\hline Monounsat. acids & 20.4 & 34.3 & 39.2 & 23.8 & 18.7 & 26.1 & 24.7 & 26.3 & 19.9 & 29.9 & 27.2 & 24.2 \\
\hline Polyunsat. acids & 37.2 & 24,3 & 29.2 & 46.7 & 39.9 & 22.9 & 42.1 & 39.5 & 52.6 & 16.1 & 41.2 & 38.1 \\
\hline Furan fatty acids & 8.1 & 20.6 & 0.9 & - & 18.5 & 34.8 & 9.9 & 一 & 6.5 & 44.8 & 4.6 & - \\
\hline $\begin{array}{ll}* 1 & \text { See Table 1. } \\
* 2 & \text { SE, Sterol esters; } \\
* 3 & \text { Trace (less than 0 } \\
* 4 & \text { Includes a small } \\
* 3 & \text { Includes a small a } \\
* & \text { See Table 3. }\end{array}$ & unt of & $18: 4(r$ & the & ee fatt & & & & & & & & \\
\hline
\end{tabular}

the testes of brook trout, bluegill, and dogfish. But, in this study, $F$ acids were not detected in the PL.

In the $\mathrm{F}$ acids found, $\mathrm{F}_{6}$ acid was the most predominant acid, amounting to from 49.5 to $80.4 \%$ of total $F$ acids and followed by $F_{4}$ and/or $F_{5}$ acids. $F_{b}{ }^{\prime}$ acid, ${ }^{7)}$ an isomer of $F_{b}$ acids was also found as a minor component (less than $2.6 \%$ of total $\mathrm{F}$ acids). Ishii et al $^{\left.{ }^{6}\right)}$ have also reported on the occurrence of $\mathrm{F}$ acids $(11.44 \%$ of total fatty acids) in the TG of chum salmon testes. It can be assumed that such unusual fatty acids are contained extensively in the lipids of marine fish as well as freshwater fish at spawning season.

The $F$ acids in the TG fatty acids increased from 20.6 to $44.8 \%$ of the total fatty acids with increase of maturity. Such change is exclusively attributed to the increase of $F_{0}$ acid as shown in Table 3. 
Table 3. Furan fatty acid composition of lipid classes of chum salmon testes ( $\%$ of total furan fatty acids)

\begin{tabular}{|c|c|c|c|c|c|c|c|c|c|c|c|c|}
\hline \multicolumn{4}{|c|}{ Testes } & \multicolumn{3}{|c|}{$\mathrm{A}^{* 1}$} & \multicolumn{3}{|c|}{$\mathrm{B}^{* 1}$} & \multicolumn{3}{|c|}{$\mathrm{C}^{* 1}$} \\
\hline$F$ acid*2 & $\mathrm{m}$ & $n$ & $\mathbf{R}$ & $\mathrm{SE}^{* 1}$ & $\mathrm{TG}^{* 4}$ & FFA $^{* 4}$ & $\mathrm{SE}$ & TG & FFA & SE & TG & FFA \\
\hline$F_{1}$ & 8 & 2 & $\mathrm{CH}_{3}$ & 1.0 & 0.3 & 5.2 & 0.5 & 0.6 & 1.0 & 1.5 & 0.4 & 2.2 \\
\hline $\mathrm{F}_{\mathrm{Z}}$ & 8 & 4 & $\mathbf{H}$ & 0.3 & 1.0 & 3.6 & 2.2 & 1.7 & 2.0 & - & 1.1 & - \\
\hline$F_{3}$ & 8 & 4 & $\mathrm{CH}_{3}$ & 0.4 & 0.5 & - & 0.5 & 0.9 & 3.0 & 7.7 & 0.7 & - \\
\hline $\mathrm{F}_{4}$ & 10 & 2 & $\mathrm{CH}_{3}$ & 12.7 & 22.2 & 18.9 & 19.5 & 23.0 & 24.2 & 12.3 & 11.4 & 8.7 \\
\hline $\mathrm{F}_{5}$ & 10 & 4 & $\mathrm{H}$ & 6.8 & 6.4 & 19.9 & 2.7 & 8.6 & 6.1 & 1.5 & 4.7 & 4.3 \\
\hline$F_{6}$ & 10 & 4 & $\mathrm{CH}_{3}$ & 75.3 & 61.7 & 49.8 & 74.6 & 59.5 & 49.5 & 76.9 & 77.5 & 80.4 \\
\hline$F_{6} * 3$ & 12 & 2 & $\mathrm{CH}_{3}$ & 1.1 & 2.0 & 2.6 & - & 1.4 & 2.0 & - & 0.7 & - \\
\hline$F_{7}$ & 12 & 4 & $\mathbf{H}$ & 2.4 & 2.5 & - & - & 0.9 & 5.1 & - & 1.1 & 4.3 \\
\hline$F_{8}$ & 12 & 4 & $\mathrm{CH}_{3}$ & - & 3.3 & - & - & 3.4 & 7.1 & - & 2.4 & - \\
\hline \multicolumn{4}{|c|}{ Total $F$ acids $* 5$ (mg/ $100 \mathrm{~g}$ testes) } & \multicolumn{3}{|c|}{54} & \multicolumn{3}{|c|}{95} & \multicolumn{3}{|c|}{30} \\
\hline
\end{tabular}<smiles>CCCC1OC(CCC(=O)O)CC1CC</smiles>

* 3 14,17-epoxy-15,16-dimethyleicosa-14,16-dienoic acid.7)

*4 SE, Sterol esters; TG, Triacylglycerols; and FFA, Free fatty acids.

*5 The values were calculated from the contents of SE, TG and FFA in the testes and from the ratios of fatty acids/fatty acid esters (e.g. 0.4 for SE and 0.9 for TG).

On the contrary, F acid contents of the SE and FFA decreased from 18.5 to $6.5 \%$ and 9.9 to $4.6 \%$ at the fully matured stage, respectively. The total amount (mg/100 $\mathrm{g}$ testes) of $\mathrm{F}$ acids in the testes also decreased from 95 to $30 \mathrm{mg}$ (Table 3 ).

There are many investigations on the lipids of salmon and trout at spawning season. However, little is known about the variation of the testis lipids during maturation. Phleger ${ }^{20}$ has revealed that ability to synthesize the TG of liver of pink salmon Oncorhynchus gorbuscha is inactivated after migration into freshwater and spawning, and further the fatty acids are transported as cholesterol esters into other tissues in order to be utilized as energy sources. Hence, it can be assumed that the decreases of the SE content, $F$ acid content in the $\mathrm{SE}$ and the total amount of $\mathrm{F}$ acids in the testes as described above, indicate the reduction of lipid metabolism in chum salmon at late spawning season. And further, the high accumulation of $F$ acids in the TG suggests the decay of lipid catabolism at late spawning season.

Presently it is unknown whether or not the F acids in fish testes have a biological role. In order to clarify the function of $F$ acids in fish physiology, it is necessary to investigate the distribution and variation of $F$ acids in the gonad tissues in more detail.

\section{Acknowledgments}

The authors wish to thank to Dr. T. Terao, Hokkaido Fish Hatchery, for providing the chum salmon testes and to Dr. K. Takano, Faculty of Fisheries, Hokkaido University, for his valuable advice on this manuscript.

\section{References}

1) R. L. Glass, T. P. Krick, D. M. Sand, C. H. Rahn, and H. Schlenk: Lipids, 10, 695-702 (1975).

2) R. L. Glass, T. P. Krick, and A. E. Eckhardt: Lipids, 9, 1004-1008 (1974).

3) C. M. Scrimgeour: J. Am. Oil. Chem. Soc., 54, 210-211 (1977).

4) F. D. Gunstone, R. C. Wijesundera, and C. M. Scrimgeour: J. Sci. Food Agric., 29, 539-550 (1978).

5) M. Yoshioka: Ann. Rep. Inst. Living Sci. Miyagi Gakuin Women's Coll., 14, 10-13 (1981).

6) K. Ishii, H. Okajima, T. Koyamatsu, Y. Okada, and H. Watanabe: Lipids, 23, 694-700 (1988).

7) T. Ota and T. Takagi: Bull. Fac. Fish. Hokkaido Univ., 34, 88-92 (1983).

8) T. Ota and T. Takagi: Bull. Fac. Fish. Hokkaido Univ., 40, 193-201 (1989).

9) R. L. Glass, T. P. Krick, D. L. Olson, and R. L. Thorson: Lipids, 12, 828-836 (1977).

10) E. G. Bligh and W. J. Dyer: Can. J. Biochem. Physiol., 37, 911-917 (1959). 
11) T. Ota and M. Yamada: Nippon Suisan Gakkaishi, 40, 707-713 (1974).

12) M. Yamada and K. Hayashi: Nippon Suisan Gakkaishi, 41, 1143-1152 (1975).

13) J. T. Davis, R. B. Bridges, and J. G. Coniglio: Biochem. J., 98, 342-346 (1966).

14) H. Takahashi, H. Kaneko, and T. Ichisugi: $J$. Hokkaido Fish. Exp. Station, 35, 8-13 (1978).

15) P. M. Jangaard, R. G. Ackman, and J. C. Sipos: J. Fish. Res. Bd. Canada, 24, 613-627 (1967).
16) R. G. Ackman and S. N. Hooper: Comp. Biochem. Physiol, 32, 117-125 (1970).

17) R. G. Ackman and S. N. Hooper: Comp. Biochem. Physiol., 24, 549-565 (1968).

18) A. K. Sen Gupta and H. Peters: Fette Seifen Anstrichm., 68, 349-360 (1966).

19) A. K. Sen Gupta: Fette Seifen Anstrichm., 74, 693-705 (1972).

20) C. F. Phleger: Lipids, 6, 347-349 (1971). 